\title{
Recycling of Used Paper Packaging for Rural Development
}

Mahanti JC*

Professional Engineer (Fellow of Institution of Engineers, India) and Life Member of Indian Pulp and Paper Technical Association, Kolkata, India

*Corresponding author: Mahanti JC, Professional Engineer (Fellow of Institution of Engineers, India) and Life Member of Indian Pulp and Paper Technical Association, Kolkata, India, Tel: 911322714081 ; E-mail: adyacon@gmail.com

Received: January 20, 2018; Accepted: February 05, 2018; Published: February 12, 2018

Copyright: @ 2018 Mahanti JC. This is an open-access article distributed under the terms of the Creative Commons Attribution License, which permits unrestricted use, distribution, and reproduction in any medium, provided the original author and source are credited.

\begin{abstract}
Paper recycling means that natural resources are used in an efficient way and it contributes to sustainable development of the country. Due to change in life style with increasing consumption and retailing, substantial quantity of paper and board is being used in packaging. These packaging are discarded once the products reach the retail outlets or the consumer and often end up as garbage adding to land and water pollution. Waste paper is a valuable raw material that is recycled to create new paper and board products. Considering the importance of Recyclables as a natural resource, Mr. Ranjit Singh Baxi, President of Bureau of International Recycling has announced that the $1^{\text {st }}$ Global Recycling Day will be observed on $18^{\text {th }}$ March 2018.

Rural development through manufacture of packaging paper and board in rural locations, using reclaimed waste paper has been suggested in this paper due to growing consumption of the same, availability of raw material from waste collection, as well as, other pertinent aspects including economic, social and environmental benefits. Presently, the rural population is mainly engaged in agriculture which is seasonal and often with low remuneration. Setting up properly planned and designed small capacity mills can be extremely efficient and competitive, besides providing alternate employment.
\end{abstract}

Keywords: Recycling; Environment; Rural employment; Paper board

\section{Introduction}

Recycling of used paper products besides providing raw material for manufacture of fresh paper, helps in protecting the environment. Recovered paper is a valuable raw material that can be reused to create new paper and board products. Almost any household paper can be recycled, including used newspapers, cardboard, packaging, stationery, 'direct mail', magazines, catalogues, greeting cards and wrapping paper. Basically, all paper grades can be produced based entirely on recovered paper as raw material [1].

Rural development means economic betterment of the rural people and greater social transformation by upgrading their living standard through providing employment opportunities and improved basic facilities. About $70 \%$ of India's population ( 1.35 billion) live in rural areas and over $50 \%$ of the country's work force are engaged in agriculture contributing only $17.9 \%$ to the GDP (Figure 1 ). Due to low remuneration and seasonal employment in the agriculture sector, there is large scale migration of adult population from rural areas to the cities often for low paid menial jobs with unhealthy living conditions. This migration is causing socio-economic problems in both the places. According to 2011 Census:

- The rural population declined from $72.19 \%$ in 2001 to $68.84 \%$ in 2011.

- Level of urbanization increased from $27.81 \%$ to $31.16 \%$ in this period.

- Out of the urban population 48.36 Crores (37.8\%) were migrants. 
growing work force is a matter of concern for the country and successive Governments are trying to address the same. Engagement of such a large part of the population in agriculture has become unviable and it cannot be considered as source of further employment generation [3]. Actually, with modern agricultural practice including larger land holdings and mechanization, requirement of personnel will decrease. Hence, alternate avenues for employment have to be created mainly through manufacturing industries. Presently in India, industry accounts for only $24.2 \%$ of the GDP and the major part i.e., $57.9 \%$ through services (Annexure I). Also, as shown in Annexures II and IIA, all the recent startups are located close to urban centers like major cities, ports etc., whereas, about $70 \%$ of the people live in 638,000 rural villages. Central and Eastern states account for only $0.2 \%$ of the startup investment. Also, Agri-tech is not at all prominent although agriculture is an important part of the Indian Economy. China provides an example of how rural industrialization can bring about significant change in rural economy and through it in the lives of the rural people as well as, stabilize population movement. Agriculture provided more than $50 \%$ of the GDP in 1952 but it fell to $14 \%$ in 2004 , during which period the rural enterprises known as Township and Village enterprises (TVEs) have contributed remarkably to rural development and economic growth. Their share has grown from none to one third of the GDP [4].

Mahatma Gandhi, was the first among our leaders to promote rural development. His concept of rural development meant self-reliance through spinning and weaving Khadi. This also provided livelihood to the rural people. His other emphasis was curb on consumption as excessive consumption causes pressure on resources and adds to wastage and pollution. He also believed that our natural resources although degraded and abused beyond sustainability, still have the potential to support our people. However, we need to discipline our resources and environment carefully [5]. His thought provoking statement "There is enough on this earth to meet the need but not the greed "has become a universal slogan for ensuring environmental protection and sustainable development.

Production of packaging paper and board is one of the industries ideally suited for being set up in rural areas. The main objective is to provide gainful employment with assured income to members of rural families throughout the year and thereby improve their living standards. However, the three pillars of Sustainable development mentioned below need to be strengthened, integrated and developed for achieving the desired results. These are:

1. Economic pillar. Growth for reducing poverty and creating employment.

2. Social pillar. Social and geographic inclusion with gender equality.

3. Environment pillar. Minimal environmental damage while pursuing development.

Suitability of setting up paper mills as mentioned, in rural areas is due to: Utilization of locally available raw materials and bio-fuels (Annexure III) [6].

Environmental benefits such as:

a. Disposal of wastes through nonpolluting operation.

b. Lower water consumption of water and consequently negligible or even, no waste water. (Effluent if any would be suitable for agriculture).

c. Lower energy consumption and feasibility of meeting part of the requirement through nonpolluting solar generation. d. Requirement of lesser number of highly skilled persons hence, maximum utilization of local surplus manpower.

e. Growing demand for paper packaging in the country.

f. Lower investment in setting up the plant.

g. Feasibility of setting up ancillary paper conversion units (Annexure 1V).

Besides providing employment, these paper mills will provide "on the job" training to the local youth and contribute to skill development. This will particularly be of help in operating and maintaining modern farm machinery and equipment [7]. Also, as part of their social responsibility, the units will contribute to development of the rural locality by promoting hygiene, education, sports and cultural activities and providing clean drinking water etc., Modern living conditions in rural areas, with better housings having running water and flush toilets, electricity (solar), cooking gas (bio), garbage disposal etc., are the consequences of increased industrial employment and not the other way around.

In 1990, a number of small (Mini) paper mills were set up in different parts of the country with adoption of Japanese model of small scale paper manufacture. The objective was to overcome the then acute shortage in availability of paper, creating middle level entrepreneurs and other socio-economic factors including dispersal of location of industries with development of backward regions. This concept was endorsed by many experts and The Indian Pulp and Paper Technical Association (IPPTA) through Mr. V. Poddar ${ }^{*}$, Founder President [8]. Also, the Government provided several incentives for setting up of these mills, particularly in designated "backward districts". While these mills achieved the desired purpose, in course of time, many of them have either expanded to larger units or have closed down. The ones that have prospered are mainly located in clusters close to urban centers and have negated the very objective of balanced rural development. It is suggested here that the concept of setting up small paper mills in rural locations is revived taking in to consideration the reasons for success and failure of the mills set up earlier. A lower capacity mill can be extremely efficient and competitive hence, less vulnerable. The key is to design the mill to suit local conditions with proper financial and technical planning and with involvement of the local population (Figure 2) [9].

The basic details of the Paper mills as proposed is outlined below:

Location: In rural area, preferably on land unsuitable for cultivation.

Land required: 3 to 5 Acres.

Products: Kraft paper (Fluting media and Test liner) and Paper board (Duplex and Grey) used for packaging (Annexure V).
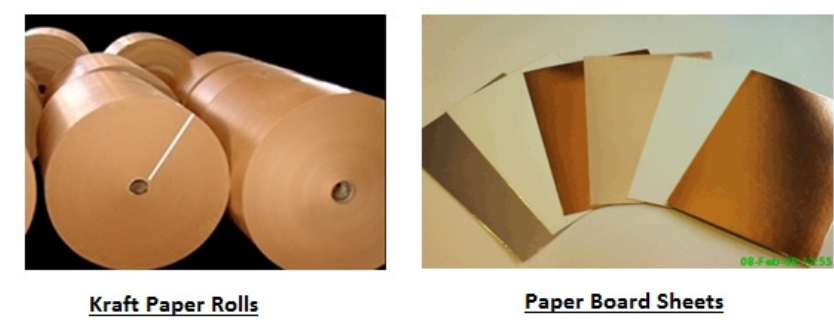

Figure 2: Kraft paper and Paper board. 
Citation: Mahanti JC (2018) Recycling of Used Paper Packaging for Rural Development. Adv Recycling Waste Manag 3: 153. doi: $10.4172 / 2475-7675.1000153$

Page 4 of 7

\begin{tabular}{|l|l|l|l|l|l|}
\hline Chemicals & 0.80 & --- & Rejects & 5.80 & 65.00 \\
\hline Fr. Water & --- & 225.00 & Effluent & --- & 98.00 \\
\hline & & & Vapor & --- & 62.50 \\
\hline Total & 51.80 & 229.50 & Total & 51.80 & 229.50 \\
\hline
\end{tabular}

Table 1: Mass Balance Manufacture of 50 Tons/Day Kraft Paper and Grey board.

\section{Employment}

125 persons (115 direct and 10 for casual and contractual jobs). Besides at least another 25 persons will be engaged in sourcing raw materials and fuels as well as, supporting services like canteen, transport etc. Addition of 150 earning members in the community will increase the demand for facilities like health care, retail outlets, restaurants, tailoring, repair shops etc. and create further employment.

Availability of raw materials: The present trend in all countries is for maximum recycling and reuse of materials due to concern for protecting the environment. This is particularly relevant in case of producing paper from forest products like wood and bamboo, as it has often resulted in deforestation as well as, water, land and air pollution [11]. Also, with growing population, the areas under forests is getting reduced with diversion of land for habitation and food production. Hence, presently used paper products (Waste paper) is the main raw material for producing paper and in developed countries e.g., Germany over $75 \%$ of the paper used is being collected and recycled to produce fresh paper (Annexure VIII).

In India, the share of waste paper as raw material for producing paper has risen from $7 \%$ in 1970 to over $50 \%$. This has reduced dependence on wood and bamboo from $84 \%$ to $30 \%$ in spite of the substantially higher paper production. However due to low collection (below 30\%), large quantities of waste paper is being imported. One of the main reasons of lower waste paper collection is that due to the small quantities available from rural areas their collection is not economical and there is no organised collection system in these places [12]. Hence, a lot of paper after use end up in garbage and are dumped in any available open public land adding to the pollution and health hazards to humans and animals. Setting up paper mills in rural areas as proposed, will result in collection of these papers and also, provide employment.

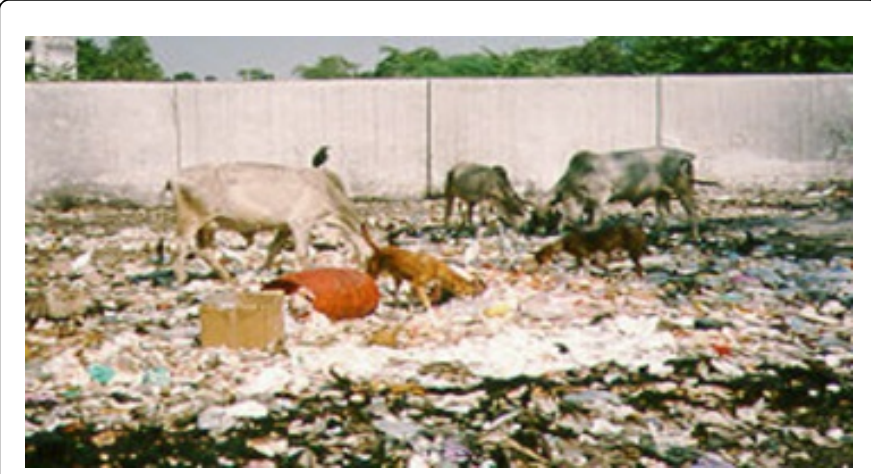

Figure 4: Garbage dumped in open land.
According to Mr. Pete Grogan, nationally recognized authority on resource recycling, who has recently received the Lifetime Achievement Award from the National Recycling Coalition, USA "Tossing paper into a landfill is not a sustainable practice, it depletes resources, wastes energy and represents a missed opportunity to participate in the multi-million dollar recycling economic sector "Recycling one Ton of corrugated container saves $390 \mathrm{Kwh}$ energy and 5 Cum. Landfill. Considering the importance of Recyclables as a natural resource, Mr. Ranjit Singh Baxi*, President of Bureau of International Recycling (BIR) has decided that the first Global Recycling Day will be observed on $18^{\text {th }}$ March 2018 (Figure 5).

Even in rural areas, most of the items of daily use like groceries, snacks and sweets, pharmaceuticals, cosmetics, garments etc., are packed in folding cartons or cardboard boxes. Also, with restrictions on use of polythene, paper carry bags and wrappings are being used at most retail outlets. Corrugated containers are used for bulk transport of almost all items. A major part of these packaging are discarded after use and will be recycled to produce fresh paper. As mentioned earlier, most of the household paper waste can be recycled however, it is important that these are kept separate from other household waste as contaminated paper is not suitable for recycling [13]. It is expected that the required raw material for the plant would be available by collection within $50 \mathrm{Kms}$ from the plant location (about $1 \mathrm{Kg} / \mathrm{month}$ per household with 125 households per square $\mathrm{km}$ and substantial quantity from shops and establishments).

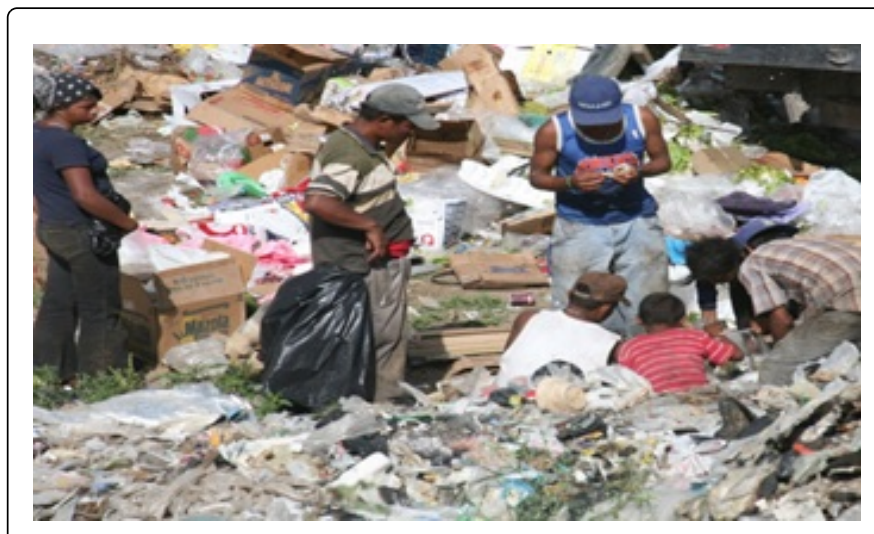

Figure 5: Collection of waste.

\section{Manual sorting and collection}

Local collection of wastepaper will significantly lower the raw material cost and add to the viability of the paper mill besides, reducing the environmental degradation. Battery operated MiniTrucks should be used to avoid air pollution (Figure 6). 
Page 5 of 7

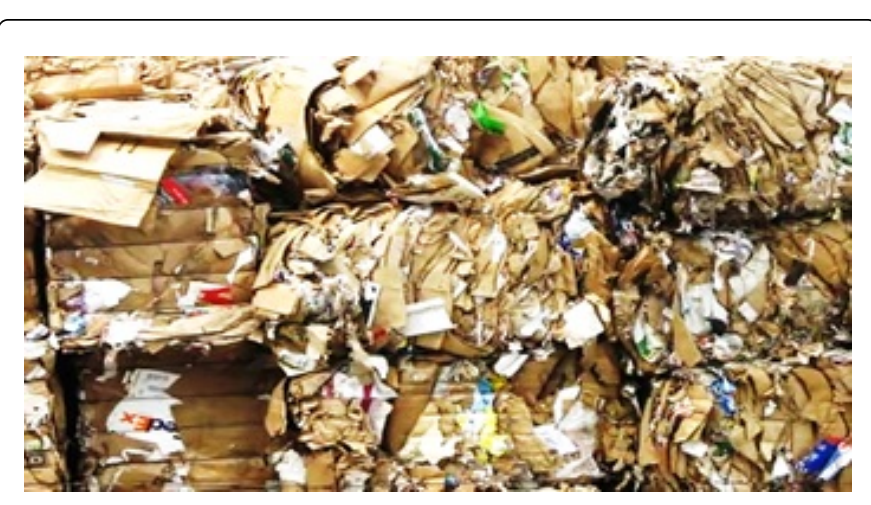

Figure 6: Mixed waste papers.

The company Lucart of France has received the 6th European Paper Recycling Award for 2017 due to developing and implementing an innovative technology for paper recycling along with Tetra Pak. The process involves separation of cellulose fibers in beverage cartons from polyethylene and aluminium parts without use of substances that are harmful to humans and the environment. The polyethylene and aluminium are converted to a material called AL.PE.

\section{Market Potential}

Production of packaging grades of paper and board has been proposed as: a. Packaging is among the high growth industries in India. Due to lower manufacturing costs, the country is fast becoming a preferred hub for sourcing packaging products by multi-national companies. The over 10,000 corrugated sheet and box making plants are employing over half a million people both directly and indirectly. The industry is converting over 3.5 million tons paper per year in to corrugated boxes. Factories are spread out in all parts of the country, even in the remotest areas. Folding carton (made from multi-ply board) market size is estimated at 2.2 million Tons. Cartons made from Grey back board constitute 50 percent and White back Coated board, Folding box board, Solid bleached board and other speciality grades account for the balance [8].

b. Consumption of packaging papers is closely linked with economic development of the country and is increasing at a very fast rate. India is witnessing rapid growth compiled with increasing production activities. This economic growth accompanied by surging affluence of the Indian population, increase in tourism and increasing exports has triggered the increase in production of consumer goods. Also, the presence of a large Asian population in the Middle east, Europe and America has led to export of provisions, condiments and ready to eat food to these countries. The requirement of packaging of these goods subsequently has created demand for packaging materials in the country.

The present consumption of different types of paper in India and the projected increase by 2018-19 is in below Figure 7.

\begin{tabular}{|lrrrrrrrr}
\hline & \multicolumn{3}{c}{ Global } & \multicolumn{3}{c}{ India 2014-15 } & \multicolumn{2}{c}{ India 2018-19 } \\
Product & \% & Mn Tons CAGR \% 4yrs & \% & Mn Tons CAGR \% 5yrs & Mn Tons CAGR \% 4yrs \\
\hline Coated & 13.2 & 41 & -2.3 & 4.8 & 0.7 & 6.7 & 0.9 & 7.0 \\
Uncoated & 14.2 & 64 & 0.0 & 25.9 & 3.8 & 5.6 & 4.8 & 5.7 \\
Packaging board & 13.7 & 58 & 1.6 & 22.2 & 3.3 & 9.4 & 4.6 & 9.1 \\
Tissue & 7.7 & 33 & 4.2 & 0.6 & 0.1 & 12 & 0.2 & 15.5 \\
Industrial Incl. kraft & 35.7 & 152 & 2.8 & 26.5 & 3.9 & 8 & 5.5 & 9.0 \\
News Print & 8 & 27 & -5.0 & 17.6 & 2.6 & 4.2 & 2.7 & 1.0 \\
Others & 7.5 & 33 & 1.6 & 2.4 & 0.3 & 7.5 & 0.5 & 8.0 \\
\hline Total & $\mathbf{1 0 0}$ & $\mathbf{4 0 8}$ & $\mathbf{0 . 9}$ & $\mathbf{1 0 0}$ & $\mathbf{1 4 . 7}$ & $\mathbf{7}$ & $\mathbf{1 9 . 1}$ & $\mathbf{6 . 8}$ \\
\hline
\end{tabular}

Figure 7: Present consumption of different types of paper in India and the projected increase by 2018-19.

According to the above, the CAGR between 2014-15 and 2018-19 for boards and Kraft papers is about $9 \%$ whereas, that for writing printing papers is $5.7 \%$. Out of the total increase in production by 4.4 million Tons, the share of packaging grades will be 66\% (Board:1.3 and Kraft:1.6 million Tons). Mr. Ranjit Singh Baxi ${ }^{* *}$ estimates that by 2025 , Kraft paper production in India will be 7 million Tons requiring about 9.5 million Tons recovered fiber. For Duplex board the figure is 5 million Tons requiring about 6.6 million Tons recovered fiber.

Assuming that half the increase in consumption will be met through expansion of the existing mills there is very good scope for setting up new units. c. Green packaging: Environmental awareness has led to increasing use of ecofriendly materials. Manufacturers are now under pressure to use material for packaging and adopt methods that have less adverse impact on the environment as a part of their extended producers responsibility (EPR). Companies engaged in sustainability efforts are focusing on meeting consumer's needs and reaching corporate objectives in a way that demonstrates continuous involvement with regard to how it affects the people and the environment. Also, use of green packaging gives advantage to industries over competitors as customers prefer products with sustainable packaging [5]. Changes in consumer preferences, rising petrochemical costs and increasing government regulations have caused food and consumer products companies to adopt paper as alternative to plastics for packaging. 
Page 6 of 7

While, glass, plastic and metals are recycled, paper is both recyclable as well as, biodegradable [14].

d. Feasibility of setting up downstream units like corrugating, box making, manufacture of paper plates, cones, tubes and other products (Annexure V).

The packaging industry in India is currently valued at Rs. 165,000 Crores ( $\$ 24.6$ billion) and is expected to grow to Rs. 210,000 Crores (\$32 billion) by 2025 (Source: Smithers-pira ${ }^{* *}$ ). Starting from packaging of fruits and vegetables, medicinal products, home and personal care products to highly dangerous and heavy industrial products, the packaging industry has led to greater specialization over a period of time. It is one of the largest markets for packaged food in the world, just behind the US, China, Brazil and Mexico, and the second-largest in Asia.

With more than 50 percent of the population younger than 25 years, increasing disposable incomes, a growing middle class, ongoing urbanization and changing lifestyles, India enjoys highly favorable demographic patterns [7]. As young people are one of the key drivers in the demand for processed and hygienic packaged foods, manufacturers are introducing products that increase convenience and reduce the time required to prepare meals. Products with additional ingredients-in easy to handle packaging and convenient package sizes will continue to gain popularity. E-tailers are also enjoying increasing online revenue sales. According to research, sellers in India have a positive sentiment towards e-commerce with maximum traction seen in food businesses. Major factors likely to influence the Packaging industry at least for the next decade are listed below:
a. Electronic business processing.
b. Convenience packaging.
c. Supply chain management.
d. Marketability.
e. Benefits like labelling, tamper evidence, freshness.
f. Environment friendly.

A number of key social and market trends are having a major impact on developments in packaging over recent years [6]. These include: the trends towards smaller households and accompanying rise in demand for more, smaller pack sizes, the increasing requirement for convenience including ready to process food and beverages and the growing use of packaged healthcare products, cosmetics etc.

Investment and financial viability

The total capital outlay for setting up the paper mills as proposed will largely depend on the location with site conditions and several other factors (Table 2). However, as an indication only, it is expected that it will be within Rs 30 Crores comprising:

\begin{tabular}{|l|l|}
\hline Item of expenditure & Cost Rs. Lacs \\
\hline Land, buildings and other constructions & 275.00 \\
\hline Main production plant & 1350.00 \\
\hline $\begin{array}{l}\text { Utilities and auxilliary plants incl. bi-product electricity } \\
\text { generation }\end{array}$ & 450.00 \\
\hline Harnessing solar energy (750 Sq.m PV and 120 sq.m CSP) & 375.00 \\
\hline Preliminary and preoperative expenses & 275.00 \\
\hline
\end{tabular}

\begin{tabular}{|l|l|}
\hline Working Capital & 250.00 \\
\hline Total & 2975.00 \\
\hline
\end{tabular}

Table 2: Investment and financial viability of paper mills.

These projects should not be treated as pure commercial ventures but should form a part of the government's schemes for social and rural development and poverty alleviation. Consequently, the following incentives and facilities should be provided [15].

Land on lease free of cost.

Site development and connecting road from Highway (through NAREGA).

Dedicated electricity supply line from the substation.

Subsidised electricity tariff.

$100 \%$ reimbursement of cost for harnessing solar energy.

Subsidy on investment.

Tax exemption and lower rate of interest on loans.

Financial viability: The operation of the mills should be financially viable as there are several favourable conditions as compared to larger units. These are mainly:

Cheaper raw materials and fuel from local collection.

Lower man power cost by utilising local inhabitants.

Savings in energy cost due to harnessing solar power to meet part of the requirement.

Lower working capital requirement since, reduced inventory of raw materials, fuel and finished products.

While, the actual figures will depend on individual cases and circumstances, even with an operating margin of Rs. 2000 per Ton paper, the investment will be paid back within 10 years and much earlier, if the incentives mentioned above are taken in to consideration.

It is advisable that units for conversion of part of the production like corrugating, carton and box manufacture etc., (Annexure V) are set up in the mill premises or nearby for generating further employment and save on transportation costs and overheads.

\section{Comments and Observations}

While, recycling of packaging paper waste has been suggested here, it is only one of the several possibilities of rural development though creating gainful employment opportunities. Some of other recycling units are listed below:

Polythene granules and mouldings/Containers, Furnitures.

Particle board.

Pulp moulding: egg trays, fruit trays etc.

Hollow bricks and other construction items.

Also agro based industries like food processing and preservation, processing of jute with production of hessian bags, ropes and other products are ideally suitable for rural development.

Naturally, many of these industries would require paper and board packaging and hence, contribute to the demand for the same. 
Citation: Mahanti JC (2018) Recycling of Used Paper Packaging for Rural Development. Adv Recycling Waste Manag 3: 153. doi: 10.4172/2475-7675.1000153

Page 7 of 7

\section{References}

1. Thakker U (2011) Gandhian Perspective of Development, Gandhian Studies Center.

2. Poddar V (1960) A guide to manufacture of paper on a small scale. IPPTA inaugural session. Rohtas Industries Ltd. Dalmia nagar.

3. Mehta R (2009) Rural Livelihood Diversification and it's measurement Issues. 2nd Annual Meeting, FAO, Rome.

4. Kumar S (2011) Rural Development through Rural Industrialization: Exploring the Chinese Experience. Asian scholarship. org. The Asian Scholarship Foundation.

5. Atkinson W (2012) The Rural Advantage. Site selection magazine.

6. Bose S, Saigal S (2004) Thinking big about small scale enterprise. ITTO Tropical Forest Update 14: 16-17.

7. Ahmed T, Pandey JK (2015) A study on development of rural areas through industries in India. Intrnatnal J Appld Res 1: 93-96.
8. Chudasama H (2016) Indian Startup Investment Report.

9. Ottenio D, Escabasse JY, Podd B (2004) Paper and Board for Food Packaging Applications. International Life Science Institute (ISLI) Wild Films India.

10. Mahanti JC (2016) Prospects of use of Solar energy in paper industry.

11. https/www.pappnews.com.india.paper.packaging.industry.outlookto-2019.

12. Nwagboso CI, Duke O (2012) Rural Development Programme in Developing Countries: The Experience of India and China. J Human Soc Sci Econom Politic Sci 12: 27-34.

13. Mohanty RN (2012) Rural Development in India and China. A comparative Perspective.

14. Ken H (2014) India Paper Industry, pp: 15-20.

15. Mahanti JC (2017) Recycling of used paper packaging (Socio-economic perspective). 